\section{Cureus}

Received 02/13/2013

Review began 02/15/2013

Published 03/26/2013

\section{Copyright 2013}

Tzamaloukas et al. This is an open access article distributed under the terms of the Creative Commons Attribution License CC-BY 3.0., which permits unrestricted use, distribution, and reproduction in any medium, provided the original author and source are credited.

\title{
Principles of Quantitative Fluid and Cation Replacement in Extreme Hyperglycemia
}

Antonios H. Tzamaloukas ${ }^{1}$, Yijuan Sun ${ }^{2}$, Nikifor K. Konstantinov ${ }^{3}$, Richard I. Dorin ${ }^{2}$, Todd S. Ing ${ }^{4}$, Deepak Malhotra ${ }^{5}$, Glen H. Murata ${ }^{2}$, Joseph I. Shapiro ${ }^{6}$

1. University of New Mexico School of Medicine 2. Raymond G. Murphy VA Medical Center; University of New Mexico School of Medicine, Albuquerque, New Mexico 3. University of New Mexico School of Medicine, Albuquerque, NM 4. Loyola University Chicago, Stritch School of Medicine, Maywood, Illinois 5. University of Toledo 6. The Joan C Edwards College of Medicine of Marshall University, Huntington, WV

$\square$ Corresponding author: Joseph I. Shapiro, shapiroj@marshall.edu

Disclosures can be found in Additional Information at the end of the article

\section{Abstract}

Hyperglycemia may cause profound deficits of water, sodium and potassium through osmotic diuresis, which continues during treatment as long as there is glucosuria. Replacement fluids should cover both the deficits at presentation and the ongoing losses during treatment. At presentation with hyperglycemia, quantitative estimates of the deficits in water, sodium and potassium are based on rapid body weight changes, which indicate changes in body water, and on the serum sodium concentration corrected to a normal serum glucose level. The corrected serum sodium concentration provides a measure of the water deficit relative to the cation deficit (sodium, plus potassium) that is useful in guiding the choice of monovalent cation concentration in the initial replacement fluids. Monitoring clinical status, serum chemistries (glucose, sodium, potassium, total carbon dioxide), urine flow rate, and urine chemistries (sodium and potassium) during the course of fluid and cation replacement therapy is critical. This monitoring guides the volume and composition of replacement solutions for deficits developing during treatment and the management of potassium balance and acid-base abnormalities, including metabolic acidosis, respiratory acidosis, rarely, and others.

Categories: Endocrinology/Diabetes/Metabolism, Internal Medicine

Keywords: osmotic diuresis, hyperglycemia, hypovolemia, hypertonicity, hypokalemia

\section{Introduction And Background}

Deficits in body water and electrolytes complicating severe hyperglycemic syndromes may aggravate their outcomes [1]. For this reason, evidence-based guidelines place emphasis on the quantity and composition of the replacement solutions [1-4]. Adherence to guidelines improves the outcomes of severe hyperglycemic syndromes [5-6]. Although the guidelines recognize the importance of fluid replacement, they recommend fixed initial rates of infusion of $0.154 \mathrm{~m}$ saline and do not provide details for the subsequent management of patients with extreme fluid deficits [1-2, 4]. Because fluid replacement in these extreme cases requires large volumes, errors can also be large. Individualizing replacement by careful computations of deficits may complement the guidelines and may prevent errors.

This report reviews the pathogenesis of fluid and solute abnormalities in hyperglycemic syndromes and describes a quantitative method for their correction. Fluid and solute losses occur both prior to presentation with hyperglycemia and during its treatment. Accurate 


\section{Cureus}

estimates of existing water and monovalent cation losses at presentation with hyperglycemia and of changes in body water and monovalent cations occurring during treatment are critical. These estimates guide individualized quantitative estimates of fluid replacement. Data from two patients with extreme hyperglycemia are used to illustrate the applications of the method presented. We suggest that simplicity without loss of accuracy is an advantage of this method. Rigorous, but more complex, methods calculating the replacement solutions have been reported [7-8]. Table 1 shows the abbreviations used in this report.

\begin{tabular}{|c|c|}
\hline Abbreviation & Explanation \\
\hline$[G l u]_{S}$ & Serum glucose concentration \\
\hline$[N a]_{S}$ & Serum sodium concentration \\
\hline$\frac{\Delta[N a]_{S}}{\Delta[G l u]_{S}}$ & $\begin{array}{l}\text { Change in serum sodium concentration as a consequence of the change in serum glucose } \\
\text { concentration }\end{array}$ \\
\hline$D-A H$ & Dialysis-associated hyperglycemia \\
\hline$D K A$ & Diabetic ketoacidosis in patients with preserved renal function \\
\hline$N K H$ & Non-ketotic hyperosmolar hyperglycemia in patients with preserved renal function \\
\hline$[O s m]_{S}$ & Serum osmolality \\
\hline$[O s m]_{U}$ & Urine osmolality \\
\hline$V_{U}$ & Urine volume \\
\hline $\mathrm{V}_{U} \mathrm{H}_{2} \mathrm{O}$ & The part of urine volume that is solute-free (pure water) \\
\hline$V_{U e} H_{2} \mathrm{O}$ & The part of urine volume that is electrolyte-free \\
\hline$[N a]_{U}$ & Sodium concentration in urine \\
\hline$[K]_{U}$ & Potassium concentration in urine \\
\hline$[C l]_{S}$ & Serum chloride concentration \\
\hline$\left[\mathrm{TCO}_{2}\right]_{S}$ & Serum total carbon dioxide \\
\hline$I C U$ & Intensive care unit \\
\hline$[K]_{S}$ & Serum potassium concentration \\
\hline$\Delta W g t=\Delta V_{\text {Body }}$ & $\begin{array}{l}\text { Body weight (body water) difference between the normal state and the state of presentation } \\
\text { with hyperglycemia. }\end{array}$ \\
\hline
\end{tabular}

TABLE 1: Abbreviations used in this report

\section{Review}

Body water (body weight) changes in hyperglycemic 


\section{Cureus}

\section{syndromes}

Rapid (e.g. hours to days) changes in body weight reflect body fluid changes of equal magnitude. The difference between the most recent previous recording of body weight and its measurement at presentation with hyperglycemia provides a quantitative estimate of the net loss in body water from hyperglycemia. Consequently, recent weight loss, when known, provides an estimate of the volume of water required to replete the water already lost at presentation. When the weight lost is not known, a reasonable approximation may be that patients presenting with severe hyperglycemia have lost about $9 \mathrm{~L}$ of fluids $[2,4]$ or $\geqslant 25 \%$ of their total body water.

Symptomatic volume deficits at presentation should be replaced promptly by infusion of large volumes of saline, often containing potassium salts, until the symptoms of hypovolemia have abated. Large fluid losses occur also during treatment, as long as serum glucose concentration $\left([G l u]_{s}\right) \quad$ remains high, and should be replaced. For this reason, weight changes during treatment should be recorded frequently [4]. Vital signs, such as the pulse rate and blood pressure, are also critical in monitoring the adequacy of fluid replacement and in guiding treatment changes.

\section{Changes in serum tonicity in hyperglycemic syndromes from gains in extracellular solute}

Serum tonicity, or effective osmolarity, is the part of total serum osmolarity attributable to extracellular solutes that don't rapidly enter cells and therefore cause steady state osmotic fluid shifts from the intracellular into the extracellular compartment when their extracellular concentration is high [9]. The clinical manifestations of hypertonicity result primarily from reductions in the volume of brain cells [10] and are neurological (headache, coma, seizures, and death).

Disturbances in serum tonicity are the consequence of imbalances in the relation between body water, total body solute and body monovalent cations. Sodium salts are the main extracellular solute. The concentration of sodium in $\operatorname{serum}\left([\mathrm{Na}]_{s}\right)$ is an accurate index of tonicity if there is no excess of extracellular solute other than sodium salts or decrease in plasma water content [11-15]. Hypernatremia indicates an abnormally high ratio body (extracellular) sodium-to-body water regardless of whether total body sodium is below normal, normal or excessive [11] and indicates, without exception, the presence of hypertonicity. Hyperglycemia is a hypertonic state which may be associated with low, "normal", or high $[\mathrm{Na}]_{s}$.

Hyperglycemia causes hypertonicity by two distinct mechanisms, extracellular solute (glucose) accumulation and osmotic diuresis. Although these two mechanisms have additive effects on tonicity, they have opposing effects on $[\mathrm{Na}]_{s}$. A gain in extracellular glucose content, without any change in body water or monovalent cations, causes hypertonicity [9]. An increase in serum glucose concentration $\left([G l u]_{s}\right)$ leads to osmotic transfer of intracellular water into the extracellular compartment resulting in dilution of extracellular solutes and hyponatremia [16]. An approximation of serum tonicity at hyperglycemia is provided by formula 1 in Table 2 [17].

\section{Formulas used in this report}

Tonicity formula:

Tonicity $=2 \times[N a]_{S}+[G l u]_{S}$ 


\section{Cureus}

when $[G l u]_{S}$ is in $\mathrm{mmol} / \mathrm{I}$

Tonicity $=2 \times[N a]_{S}+\frac{[G l u]_{S}}{18}$

when $\left([G l u]_{S} \quad\right.$ ) is in $\mathrm{mg} / \mathrm{dl}$

The Katz formula (20):

$\frac{\Delta[N a]_{S}}{\Delta[G l u]_{S}}=-0.2857 \mathrm{mEq} / \mathrm{l}$ per $\mathrm{mmol} / \mathrm{l}$

or

$\frac{\Delta[\mathrm{Na}]_{S}}{\Delta[\mathrm{Glu}]_{S}}=-1.6 \mathrm{mEq} / \mathrm{l}$ per $100 \mathrm{mg} / \mathrm{dl}$

$\Delta[G l u]_{S} \quad=$ change in $[G l u]_{S} \quad . \Delta[N a]_{S} \quad=$ change in $[N a]_{S}$ resulting from $\Delta[G l u]_{S}$

Corrected $[N a]_{S} \quad$ (21):

Corrected $[N a]_{S}=[N a]_{S}+0.2857 \times\left([G l u]_{S}-5.6\right)$

when $[G l u]_{S}$ is expressed in $\mathrm{mmol} / \mathrm{l}$, or

Corrected $[N a]_{S}=[N a]_{S}+1.6 \times\left(\frac{[G l u]_{S}-100}{100}\right)$

when $[G l u]_{S}$ is expressed in $\mathrm{mg} / \mathrm{dl}$

Solute-free water loss in the urine $\left(\mathrm{V}_{U} \mathrm{H}_{2} \mathrm{O}\right)$ :

$V_{U} H_{2} O=V_{U} \times\left(1-\frac{[O s m]_{U}}{[O s m]_{S}}\right)$

$V_{U}=$ the urine volume in the period studied

Electrolyte-free water loss in the urine $-V_{U e} H_{2} O-(39)$

$V_{U e} H_{2} O=V_{U} \times\left(1-\frac{[N a]_{U}+[K]_{U}}{[N a]_{S}}\right)$

$[N a]_{U} \quad,[K]_{U} \quad=$ urinary sodium and potassium concentration respectively.

The Mellits-Cheek formula for boys (43):

$V_{\text {normal }}=-21.993+0.406 \times$ Weight $_{\text {Normal }}+0.209 \times$ Height

$V_{\text {Normal }}$, the body water in the normal state, is in liters, Weight $t_{\text {Normal }}$

is in kilograms and Height

is in 


\section{Cureus}

centimeters

\section{TABLE 2: Formulas used in this report}

Conversely, the literature [18-19] provides both indirect and direct evidence strongly suggesting that serum tonicity decreases during correction of hyperglycemia without any further changes in body water or monovalent cations.

Indirectly, a balance study reported net loss of body solute not accounted for by changes in the external balances of solute or water during correction of hyperglycemia [18]. Directly, serum tonicity decreased in anuric patients during correction of hyperglycemia by the use of only insulin infusion [19]. Therefore, the formula estimating serum tonicity at hyperglycemia (formula 1 in Table 2) is not appropriate as a guide to the tonicity of the initial replacement solution. What is needed is an accurate prediction of the final euglycemic $[\mathrm{Na}]_{s}$ if hyperglycemia were to be corrected without any further changes in water or cation balances.

Katz [20] proposed that a decrease in $[G l u]_{s}$ by $5.6 \mathrm{mmol} / \mathrm{L}(100 \mathrm{mg} / \mathrm{dL})$ results in an increase in $[N a]_{s}$ by $1.6 \mathrm{mEq} / \mathrm{l}\left(\frac{\Delta[N a]_{s}}{\Delta[G l u]_{s}} \quad=-1.6 \mathrm{mEq} / 1\right.$ per $5.6 \mathrm{mmol} / \mathrm{L}$ or $-0.2857 \mathrm{mEq} / 1$ per mmol/L, formula 2 in Table 2). Al-Kudsi, et al. [21] used Katz's formula to predict the corrected $[N a]_{s}$, that is the value of $[\mathrm{Na}]_{s}$ if hyperglycemia is corrected to a $[G l u]_{s}$ of $5.6 \mathrm{mmol} / \mathrm{L}$ without any further changes in body water or cations (formula 3 in Table 2). The corrected $[N a]_{s}$ predicts serum tonicity after normalization of $[G l u]_{s}$ and should guide the selection of the tonicity of replacement fluids.

Unlike severe volume deficits which should be corrected promptly, correction of severe abnormalities in tonicity should be slow. The hourly rate of decline in serum tonicity proposed in the evidence-based guidelines is $\leqslant 3 \mathrm{mOsm} / \mathrm{l}[2]$. The rationale for this proposal is prevention of cerebral edema, which is a devastating complication of severe hyperglycemia associated usually with ketoacidosis. It has also been reported that both the magnitude and the rate of development of hyperglycemic hypertonicity are important causes of severe neurologic manifestations in hyperglycemia [22].

A decrease in $[G l u]_{s}$ by $5.6 \mathrm{mmol} / \mathrm{L}$ without any other change would cause a $5.6 \mathrm{mOsm} / \mathrm{l}$ decrease in serum tonicity, while an increase in $[\mathrm{Na}]_{s}$, by $1.6 \mathrm{mEq} / \mathrm{l}$ would cause an increase in serum tonicity by 3.2 (= 2 x 1.6) $\mathrm{mOsm} / \mathrm{l}$. Therefore, the net effect of correction of hyperglycemia, according to Katz's formula (20), would be a decrease by 2.4 (= $5.6-3.2) \mathrm{mOsm} / \mathrm{l}$ for each decline in $[G l u]_{s}$ by $5.6 \mathrm{mmol} / 1$ [19]. The hourly rate of decline in $[G l u]_{s}$ proposed in the guidelines [2], at 2.8-4.2 $\mathrm{mmol} / 1$ (50-75 mg/dl), would thus produce a rate of decline in serum tonicity between 1.2 and $1.8 \mathrm{mmol} / \mathrm{l}$ per hour. Corrected $[\mathrm{Na}]_{s}$ should also decrease, if its presenting value is elevated. With the recommended rate of decline in tonicity through correction of hyperglycemia, the desired rate of decline in corrected $[\mathrm{Na}]_{s}$ is $0.6-0.9 \mathrm{mEq} / \mathrm{l}$ hourly.

Figure 1 shows the relation between $[G l u]_{s}$, measured $[N a]_{s}$, serum tonicity and corrected $[\mathrm{Na}]_{s}$ defined by the Katz [20] and Al-Kudsi [21] formulas. The important feature of this Figure is that the corrected $[N a]_{s}$ is equal to the measured $[N a]_{s}$ at euglycemia and is the only parameter that remains constant throughout the range of hyperglycemia. Therefore, the corrected $[\mathrm{Na}]_{s}$ represents the most appropriate parameter for evaluating tonicity during 
treatment of hyperglycemic syndromes. The provision for this use of corrected $[N a]_{s}$ is that clinical observations should confirm Katz's theoretical calculation, which is based on a closed system without any changes in the external balance of monovalent cations or water.

Observations in patients with end-stage renal disease, who, by and large, represent closed systems, confirmed Katz's number [19, 23-26]. An example of the effect of correction of anuric hyperglycemia on serum tonicity is shown below.

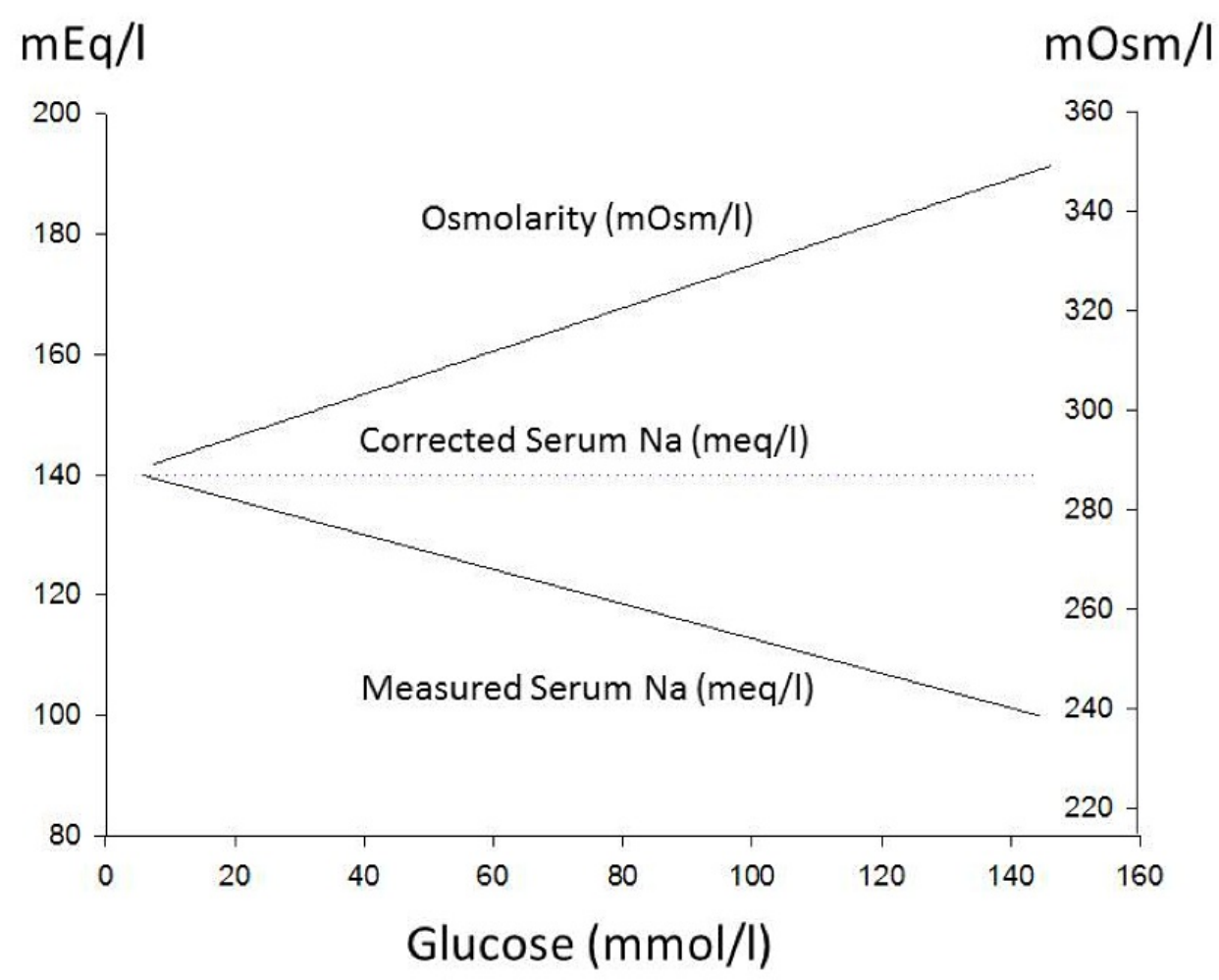

\section{FIGURE 1: Changes in serum tonicity, measured serum sodium concentration and corrected serum sodium concentration in progressive hyperglycemia}

Changes in serum tonicity, measured serum sodium concentration and corrected serum sodium concentration in progressive hyperglycemia predicted by Katz [20] and Al-Kudsi et al. [21]. Regardless of the level of hyperglycemia, which affects both serum tonicity and measured serum sodium concentration, the corrected serum sodium concentration remains constant and equal to the baseline measured serum sodium concentration.

Table 3 shows sequential changes in serum chemistries in an anuric man (Patient 1), who had exhibited intense thirst and consumption of large volumes of water in the two days prior to admission with hyperglycemia and was treated with insulin infusion. Body weight measurements were exactly the same at presentation and after correction of hyperglycemia 16 hours later. The main findings of Table 3 are as follows: (a) Each decrease in $[G l u]_{s}$ was accompanied by an increase in $[N a]_{s}$ and a decrease in serum tonicity, while the corrected $[N a]_{s}$ remained the same in each step and was equal to the measured final euglycemic $[N a]_{s}$. These findings are consistent with Figure 1. (b) The average hourly rate of decline in $[\mathrm{Na}]_{\mathrm{s}}$ was $3.9 \mathrm{mmol} / \mathrm{L}(70.2 \mathrm{mg} / \mathrm{dL})$ and the average hourly rate of decrease in tonicity was $1.78 \mathrm{mmol} / \mathrm{L}$. Both rates of decline were within the rates recommended by the guidelines [2]. (c) 


\section{Cureus}

Overall $\frac{\Delta[\mathrm{Na}]_{s}}{\Delta[\mathrm{Glu}]_{s}} \quad$ was $-1.55 \mathrm{mEq} / \mathrm{l}$ per $5.6 \mathrm{mmol} / \mathrm{L}$ and tonicity decreased by $2.46 \mathrm{mOsm} / \mathrm{l}$ per

$5.6 \mathrm{mmol} / \mathrm{L}$ decrease in $[G l u]_{s}$. These estimates confirm Katz's predictions [20]. (d) At euglycemia, the patient exhibited substantial hypotonic hyponatremia, an apparent consequence of water intake during development of hyperglycemia.

\begin{tabular}{|c|c|c|c|c|c|c|c|}
\hline $\begin{array}{l}\text { Glucose } \\
\text { mmol/L } \\
\text { (mg/dL) }\end{array}$ & $\begin{array}{l}\text { Sodium } \\
\text { Measured } \\
\text { mEq/I }\end{array}$ & $\begin{array}{l}\text { Potassium } \\
\text { mEq/l }\end{array}$ & $\begin{array}{l}\text { Chloride } \\
\mathrm{mEq} / \mathrm{l}\end{array}$ & $\begin{array}{l}\text { Total CO2 } \\
\mathrm{mmol} / \mathrm{L}\end{array}$ & $\begin{array}{l}\text { Anion Gap } \\
\mathrm{mEq} / \mathrm{L}\end{array}$ & $\begin{array}{l}\text { Tonicity } \\
\text { mOsm/l }\end{array}$ & $\begin{array}{l}\text { Sodium } \\
\text { Corrected } \\
\mathrm{mEq} / \mathrm{l}\end{array}$ \\
\hline 68.9 (1240) & 103 & 5.7 & 69 & 22 & 12 & 274.9 & 121.2 \\
\hline 47.6 (856) & 109 & 4.6 & 75 & 22 & 12 & 265.5 & 121.1 \\
\hline $34.0(612)$ & 113 & 4.1 & 80 & 22 & 11 & 260.0 & 121.2 \\
\hline 23.5 (423) & 116 & 3.9 & 82 & 22 & 12 & 255.5 & 121.2 \\
\hline $4.4(80)$ & 121 & 3.9 & 87 & 21 & 13 & 246.4 & 120.7 \\
\hline
\end{tabular}

TABLE 3: Sequential serum chemistry values in an anuric hyperglycemic patient treated with insulin infusion. Patient 1.

On admission with extreme hyperglycemia, serum urea was $50.4 \mathrm{mmol} / \mathrm{l}$ and measured serum osmolality $338 \mathrm{mOsm} / \mathrm{kg}$. At euglycemia, serum urea was $51.1 \mathrm{mmol} / \mathrm{l}$ and measured serum osmolality $311 \mathrm{mOsm} / \mathrm{kg}$.

On admission with extreme hyperglycemia, serum urea was $50.4 \mathrm{mmol} / \mathrm{l}$ and measured serum osmolality $338 \mathrm{mOsm} / \mathrm{kg}$. At euglycemia, serum urea was $51.1 \mathrm{mmol} / \mathrm{l}$ and measured serum osmolality $311 \mathrm{mOsm} / \mathrm{kg}$.

\section{Effects on serum tonicity of losses of water and monovalent cations from glucosuria}

The management of hypertonicity can become a central concern during treatment of hyperglycemia in patients with preserved renal function who, unlike patients with absent renal function, develop external losses of water, sodium and potassium causing rises in tonicity that are added to those caused by hyperglycemia. Unlike hypertonicity caused by hyperglycemia, which requires only insulin for its reversal $(25,27)$, hypertonicity resulting from external losses of fluids must be corrected by careful choice of the volume and composition of the replacement solutions.

Figure 2 shows simulated $[N a]_{s}$, measured and corrected, resulting from simultaneous development of both hyperglycemia and osmotic diuresis with varying degrees of electrolytefree water loss in the urine. Progressive urinary loss of electrolyte-free water causes rises in both measured $[\mathrm{Na}]_{s}$, which may exceed the normal range of $[\mathrm{Na}]_{s}$ despite an osmotic shift of intracellular water into the extracellular compartment, and corrected $[N a]_{s}$, which provides a true reflection of the relative water deficit. 


\section{Cureus}

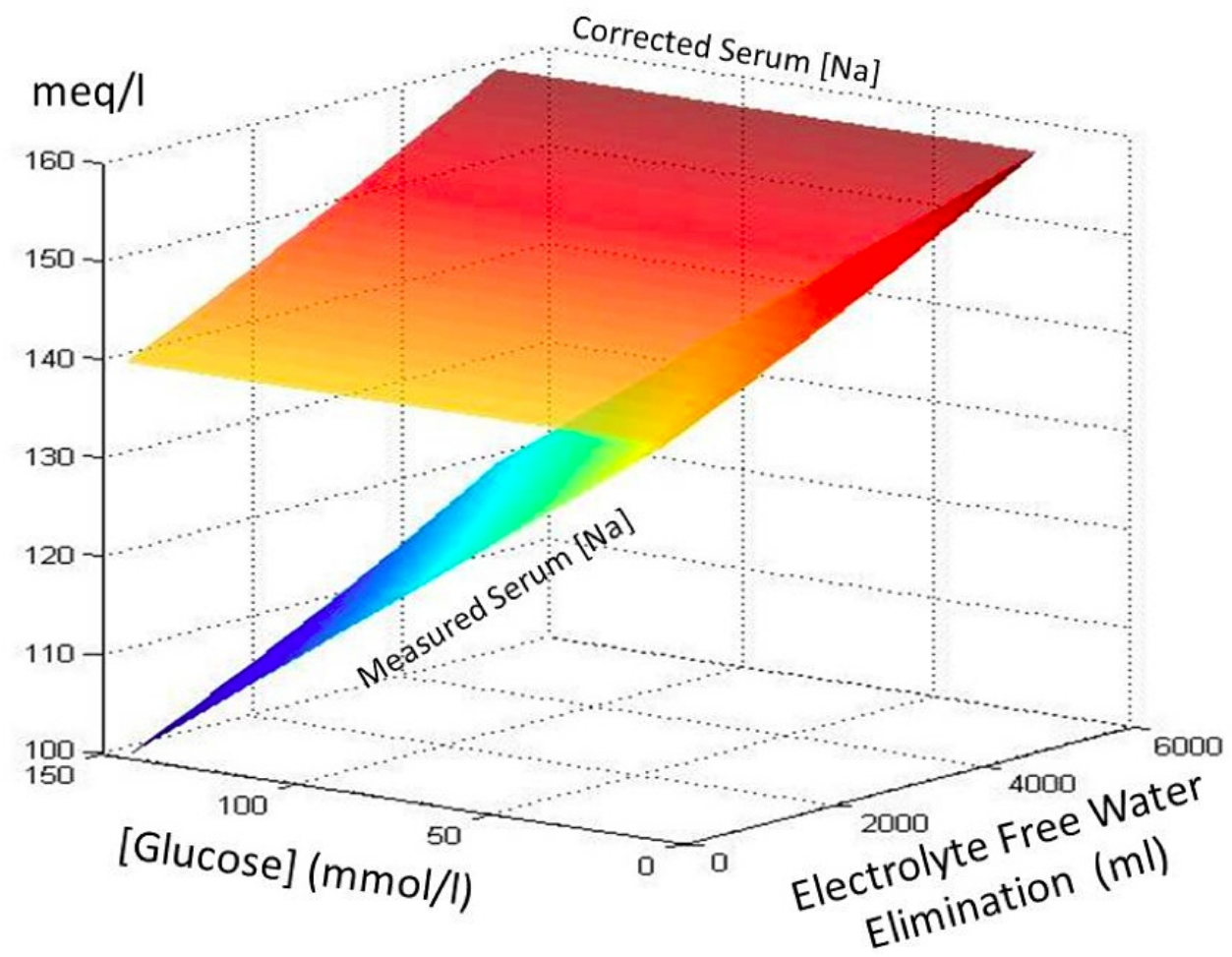

\section{FIGURE 2: Relationship between measured and corrected serum sodium, serum glucose and electrolyte-free water elimination in the urine}

Relationship between measured and corrected serum sodium, serum glucose and electrolytefree water elimination in the urine. The measured and corrected serum sodium values were calculated according to Katz (20) and Al-Kudsi et al. (21). The electrolyte-free water elimination in these simulations is a calculated value considering only electrolyte-fee water loss and assuming initial measured serum sodium concentration of $140 \mathrm{mEq} / \mathrm{l}$, serum (and total body) potassium held constant and an initial body water of 40 liters. Please note that the values of measured and corrected serum sodium concentration are the same when electrolyte-free water elimination is zero.

Figure 3 illustrates hypertonicity caused by hyperglycemia alone and by a combination of hyperglycemia, plus external losses in actual hyperglycemic syndromes. This Figure shows the average values of $[G l u]_{s},[N a]_{s}$, and corrected $[N a]_{s}$ from large numbers of episodes of dialysis-associated hyperglycemia (D-AH), and diabetic ketoacidosis (DKA) and nonketotic hyperosmolar hyperglycemia (NKH) in patients with preserved renal function [25]. In D-AH, the average corrected $[N a]_{s}$ was slightly below the normal range of $[N a]_{s}$, because hyperglycemia causes thirst and fluid consumption, which is translated in weight gain [28-30], modestly depressed values of corrected $[\mathrm{Na}]_{s}$ and, in approximately one-third of the episodes, usually modest hypotonicity after correction of the hyperglycemia with insulin [24]. Severe hypertonicity, reported in the past in DAH episodes after dialysis with $7 \%$ dextrose dialysate, which is not available nowadays, has not been reported recently. 


\section{Cureus}

$\mathrm{mmol} / \mathrm{l}$ or $\mathrm{meq} / \mathrm{l}$

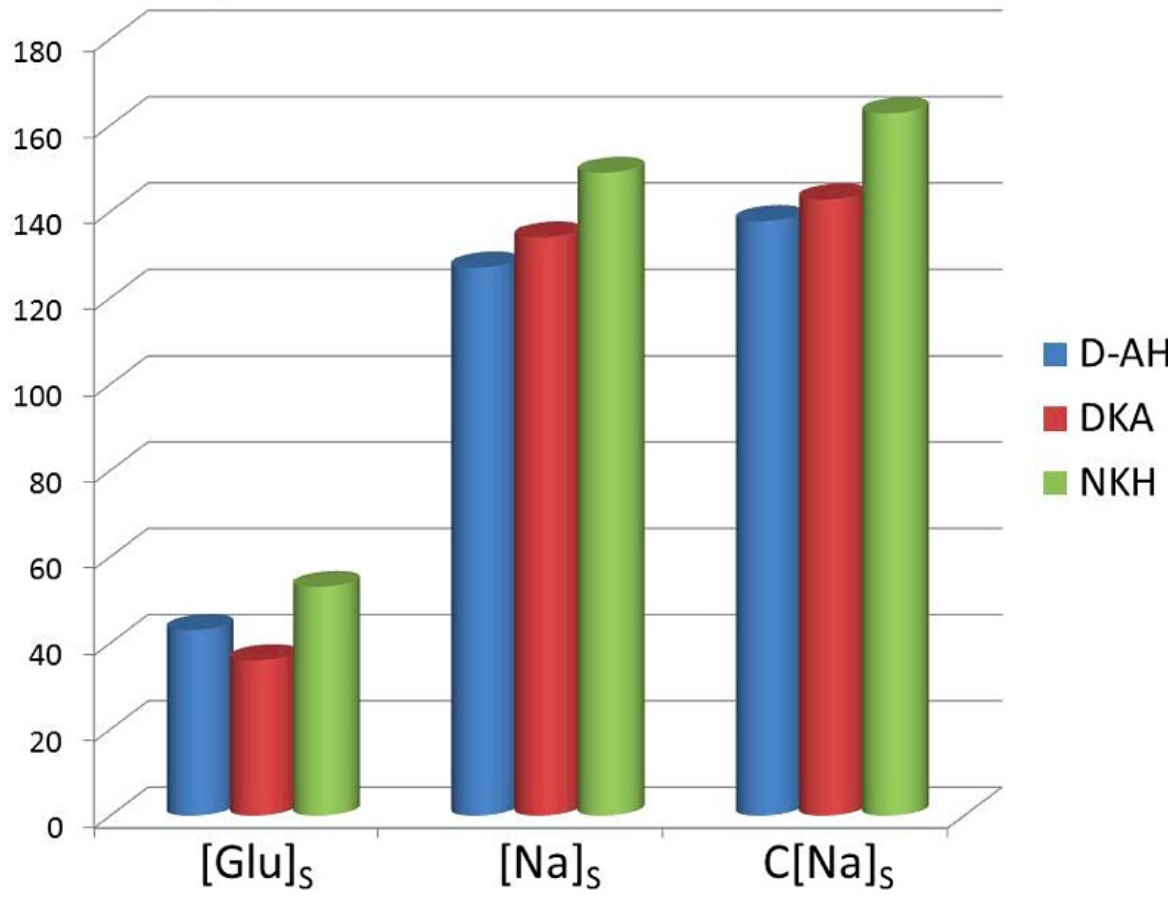

FIGURE 3: Average serum glucose ([Glu]S, in $\mathrm{mmol} / \mathrm{l}$, plus measured ([Na]S and corrected serum sodium (C[Na]S) concentrations, in $\mathrm{mEq} / \mathrm{L}$

Average serum glucose ([Glu]S, in mmol/l, plus measured ([Na]S and corrected serum sodium (C[Na]S) concentrations, in $\mathrm{mEq} / \mathrm{L}$, from a review analyzing 491 episodes of dialysis-associated hyperglycemia (D-AH), 1036 episodes of diabetic ketoacidosis (DKA) with preserved renal function and 403 episodes of non-ketotic hyperglycemia with hypertonicity (NKH) in patients with preserved renal function [25].

Average reported corrected $[\mathrm{Na}]_{s}$ was modestly above the normal range in DKA and substantially above normal in $\mathrm{NKH}$, in which average measured $[\mathrm{Na}]_{s}$ was also above the normal range, despite the extreme hyperglycemia (Figure 3). These findings in actual patients verify Figure 2.

Figure 4 shows percentages of the rise in tonicity above normal attributed to hyperglycemia and to changes in the external balances of water, sodium and potassium in the cases analyzed in Figure 3. Katz's estimate of a rise in serum tonicity by $2.4 \mathrm{mOsm} / \mathrm{l}$ for each $5.6 \mathrm{mmol} / \mathrm{l}$ rise in $[G l u]_{s}$ was used to calculate the part of the rise in tonicity attributable to hyperglycemia in Figure 4. The question as to whether Katz's estimate is applicable to hyperglycemia developing in patients with preserved renal function has been addressed by theoretical analyses [31], retrospective observations [32-34] and prospective studies [35]. These studies found a wide variation of the value $\frac{\Delta[\mathrm{Na}]_{s}}{\Delta[\mathrm{Glu}]_{s}}$, at random variance with Katz's prediction despite the analysis performed or the study type.

All studies of the effect of hyperglycemia on $[\mathrm{Na}]_{s}$ in patients with preserved renal function [31-35] addressed development of hyperglycemia. Osmotic water translocation from the 


\section{Cureus}

intracellular into the extracellular compartment, the only abnormality involved in Katz's calculations, is not the only, or even the largest influence, on $[\mathrm{Na}]_{s}$ during development of hyperglycemia in many cases (Figure 4). The question that needs to be addressed is whether the corrected $[\mathrm{Na}]_{s}$ based on Katz's formula provides an accurate prediction of the final euglycemic $[\mathrm{Na}]_{s}$. This question cannot be easily addressed by clinical studies because of the need for infusion of large volumes of saline during treatment of severe hyperglycemia [1-4]. Theoretical calculations suggest that the error of Katz's formula is much smaller during correction of hyperglycemia, if no further changes in water and cation balance take place, than during the development of hyperglycemia, allowing the use of the corrected $[\mathrm{Na}]_{s}$ as a guide of the tonicity of the initial replacement solutions (Tzamaloukas, et al., unpublished observation). Recent analyses of changes in $[\mathrm{Na}]_{s}$ during various states causing fluid abnormalities, including hyperglycemia [36], have adopted Katz's formula.

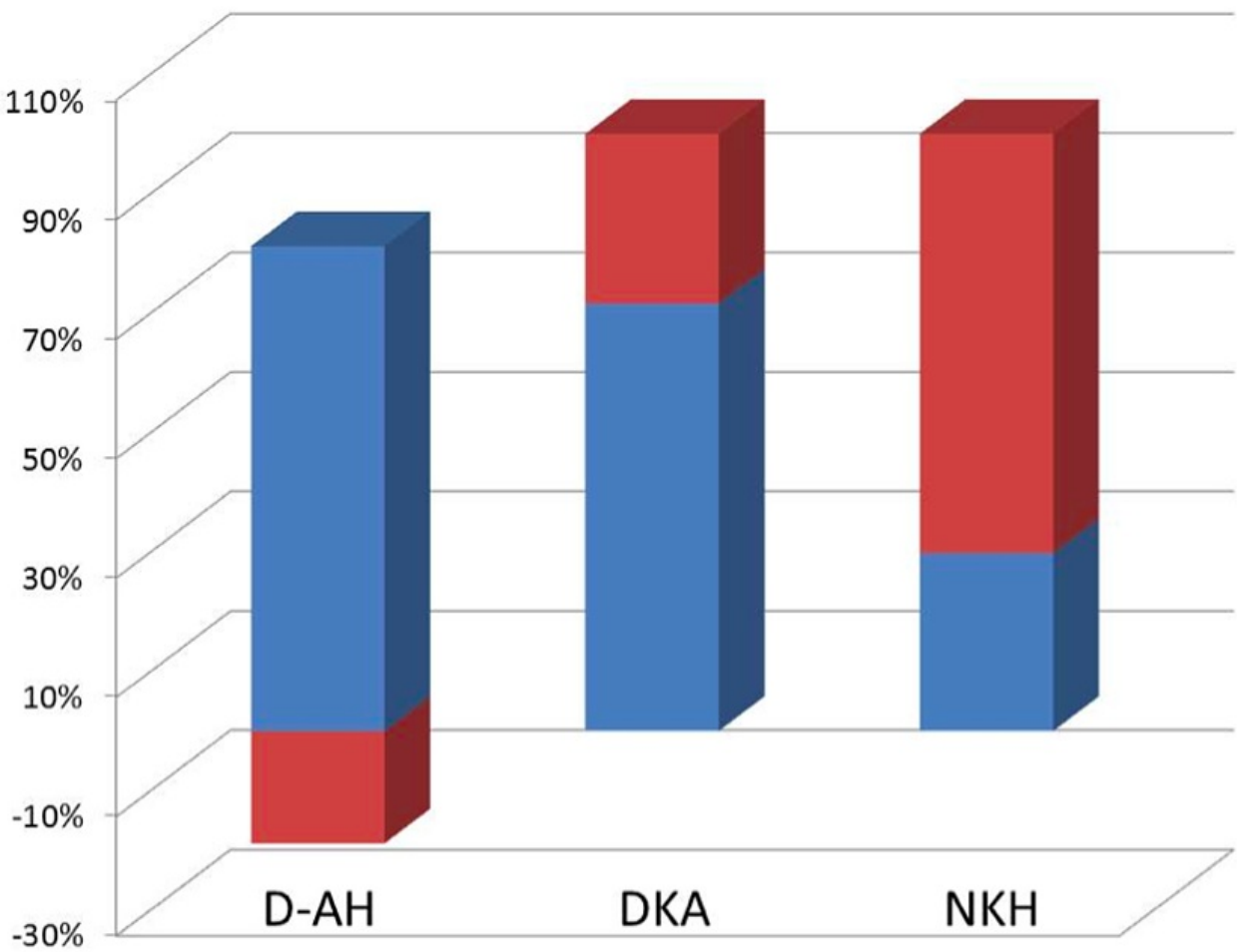

\section{FIGURE 4: Percent of hypertonicity}

Percent of hypertonicity (serum tonicity above $285.6 \mathrm{mOsm} / \mathrm{l}$ ) attributable to hyperglycemia (blue), using Katz's calculation that a $5.6 \mathrm{mmol} / \mathrm{l}$ rise in serum glucose concentration causes a $2.4 \mathrm{mOsm} / \mathrm{I}$ rise in serum tonicity $(19,20)$, and to the net external losses of water and monovalent cations (red) in the patients shown in Figure 3. Note that in patients with NKH and preserved renal function the percent of hypertonicity attributable to hyperglycemia was substantially lower than in the other two hyperglycemic syndromes even though NKH patients had a higher serum glucose concentration. This reflects the extreme hypertonicity of the NKH group.

In $\mathrm{D}-\mathrm{AH}$, the average rise in serum tonicity was less than the value calculated by Katz' formula because of retention of the ingested water (Figure 4). In DKA, approximately two-thirds of the rise in tonicity was caused by hyperglycemia and one-third by changes in the external balances, while in NKH more than two-thirds of the rise in serum tonicity were attributed to external 
losses despite a higher mean $[G l u]_{s}$ value in this hyperglycemic subset than in D-AH or DKA (Figure 3). As shown in Figure 2 and Figure 3, hypernatremia rather than hyponatremia, has been observed in extreme cases of hyperglycemia in patients with substantial renal function $[25,37]$. Hypernatremia is an index of extreme hypertonicity in hyperglycemia.

Understanding the pathogenesis of hypertonicity resulting from glucosuria requires an analysis of body water and monovalent cation balances in this clinical setting. Osmotic diuresis is a consequence of the presence in the serum of large quantities of solutes that cross freely the glomerular filter, but exhibit various degrees of resistance to tubular reabsorption [38]. Solutes responsible for osmotic diuresis may be distributed either in total body water (e.g. urea) or in the extracellular compartment (e.g. glucose in hyperglycemic states). Osmotic diuresis caused by glucosuria [39] may lead to large body deficits in water, deficits in electrolytes, mainly sodium and potassium, and hypertonicity.

For any type of diuresis, including osmotic diuresis, the effect of the urinary losses of solute and water on serum tonicity was traditionally analyzed by assuming that urine volume consists of two parts, isotonic losses and either a) pure water loss if urine osmolality $\left([\mathrm{Osm}]_{U}\right)$ is less than serum osmolality $\left([\mathrm{Osm}]_{S}\right)$, or b) net reabsorption of filtered water above the reabsorption of solute if $[\mathrm{Osm}]_{U}$ is higher than $[\mathrm{Osm}]_{S}$. The formula for solute-free water loss in the urine $\left(\mathrm{V}_{U} \mathrm{H}_{2} \mathrm{O}\right.$, formula 4 of Table 1) utilizes $[\mathrm{Osm}]_{U}$ and $[\mathrm{Osm}]_{S}$ as determinants of $\mathrm{V}_{U} \mathrm{H}_{2} \mathrm{O}$.

In osmotic diuresis $[\mathrm{Osm}]_{U}$ is higher than $[\mathrm{Osm}]_{S} \quad$ [39-40]. This finding, universal in the absence of diabetes insipidus [41], led to the conclusion that a mechanism for relative water conservation is operative in osmotic diuresis [40]. However, the effect of osmotic diuresis on serum tonicity is exerted not through the relative losses of water and total solute, but through the relative losses of water and electrolytes (sodium, plus potassium) in the urine. This is a consequence of the observation that the only determinant of $[\mathrm{Na}]_{S}$ in the euglycemic state is the ratio of the sum of total body sodium, plus total body potassium over total body water [42]. The electrolyte-free urine flow rate $\left(V_{U e} H_{2} O\right)$ substitutes the sum of urinary sodium and potassium concentrations $\left([\mathrm{Na}]_{U}+[\mathrm{K}]_{U}\right) \quad$ for $[\mathrm{Osm}]_{U}$ and $[\mathrm{Na}]_{S} \quad$ for $[\mathrm{Osm}]_{S}$ in the solute-free urine volume formula (43). Formula $V_{U e} \mathrm{H}_{2} \mathrm{O}$ (formula 5 in Table 1), but not formula $V_{U} \mathrm{H}_{2} \mathrm{O}$, determines the effect of urinary water and electrolyte losses on the euglycemic $[\mathrm{Na}]_{S}$ (that is on serum tonicity). The sum $[\mathrm{Na}]_{U}+[\mathrm{K}]_{U} \quad$ is less than $[\mathrm{Na}]_{S}$ in osmotic diuresis [39]. Therefore, water loss is relatively greater than electrolyte loss [39] and osmotic diuresis inadequately compensated for water loss leads to hypernatremia and hypertonicity [44-46].

In summary, hyperglycemia exerts two opposite influences on $[\mathrm{Na}]_{S}$. The osmotic transfer of intracellular fluid into the extracellular compartment causes decreases in $[\mathrm{Na}]_{S}$. Correction of this change in $[\mathrm{Na}]_{S}$ requires only correction of hyperglycemia and no fluid infusions, because correction of the hyperglycemia will correct the internal fluid maldistribution. The hyperglycemic osmotic diuresis causes a disproportionately larger loss of water than of sodium and potassium resulting in rises in $[\mathrm{Na}]_{S}$. Replacement of losses secondary to osmotic diuresis that were acquired prior to presentation requires an estimate of the $[\mathrm{Na}]_{S}$ value that would result if osmotic diuresis were the only influence on $[\mathrm{Na}]_{S} \quad$ (the corrected $[\mathrm{Na}]_{S}$ ).

\section{Calculations of water and cation deficits in severe hyperglycemia}

Diabetic ketoacidosis is considered severe when $[G l u]_{S} \quad>13.9 \mathrm{mmol} / \mathrm{l}(250 \mathrm{mg} / \mathrm{dl})$, arterial pH 


\section{Cureus}

$<7.00$, serum bicarbonate $<10 \mathrm{mmol} / \mathrm{L}$, serum tonicity variable, serum anion gap

$\left([\mathrm{Na}]_{S}-\left\{[\mathrm{Cl}]_{S}+\left[\mathrm{TCO}_{2}\right]_{S}\right\}\right) \quad>12 \mathrm{mEq} / \mathrm{l}$, where $[\mathrm{Cl}]_{S}$ and $\left[\mathrm{TCO}_{2}\right]_{S}$ are respectively the serum chloride and total $\mathrm{CO} 2$ concentrations, and presence of stupor or coma. Hyperglycemic hyperosmolar syndrome is considered as severe if $[G l u]_{S}>33.3 \mathrm{mmol} / \mathrm{l}(600$ $\mathrm{mg} / \mathrm{dl}$ ), arterial $\mathrm{pH}>7.30$, serum bicarbonate $>15 \mathrm{mEq} / \mathrm{l}$, serum tonicity $>320 \mathrm{mOsm} / \mathrm{l}$, serum anion gap is variable, and stupor or coma are present [1].

The calculations of this section should be used as a supplement to the established guidelines for patients with severe hyperglycemia [1-2, 4]. These calculations are based on measurements of weight, serum tonicity, and net water and cation losses. Table 4 shows the proposed sequence of calculations. Losses of water, sodium and potassium through osmotic diuresis occur in two stages, during development of hyperglycemia and during treatment while $[G l u]_{S}$ remains elevated. Replacement solutions should reflect, in both volume and composition, the calculated losses in these stages.

\section{Water and Electrolyte Deficits on Admission}

Weight deficit: $\Delta W g t$

1

DeltaWgt $=W e i g h t_{\text {normal }}-W e i g h t_{\text {Hyperglycemia }}$

2

Body water in the normal state: $V_{B o d y N o r m a l}$

Obtained from available anthropometric formulas using sex, age,

height, weight, and in some instances race

Total body sodium plus potassium in the normal state: $(N a+K)_{\text {BodyNormal }}$

3

$(N a+K)_{\text {BodyNormal }}=140 \times V_{\text {BodyNormal }}$

Body water on admission with hyperglycemia prior to any treatment: $V_{\text {BodyHyperglycemia }}$

4

$V_{\text {BodyHyperglycemia }}=V_{\text {BodyNormal }}-\Delta W g t$

5 Total body sodium plus potassium at hyperglycemia: $(N a+K)_{\text {BodyHyperglycemia }}$

Total sodium plus potassium deficit on admission with hyperglycemia: $\Delta(N a+K)_{\text {BodyHyperglycemia }}$

$6 \Delta(N a+K)_{\text {BodyHyperglycemia }}=(N a+K)_{\text {BodyNormal }}-(N a+K)_{\text {BodyHyperglycemia }}$

Volume deficit (required volume of replacement solution): $\Delta V_{B o d y}$

7

$\Delta V_{\text {Body }}=\Delta W g t$

Electrolyte composition of replacement solution: $([N a]+[K])_{\Delta V B o d y}$

$8([N a]+[K])_{\Delta V \text { Body }}=\frac{\Delta(N a+K)_{\text {BodyHyperglycemia }}}{\Delta V_{\text {Body }}}$ 


\section{Cureus}

\section{ONGOING FLUID AND ELECTROLYTE LOSSES DURING TREATMENT}

1 Urine flow rate. Monitoring from treatment onset: $V_{U}$

Measurements in the first urine sample, prior to the starting any infusion, and repeatedly as $[G l u]_{S}$ decreases:

2

$[N a]_{U},[K]_{U}, V_{U}$

Calculation of replacement solution $\left(\Delta V_{\text {Added }}\right)$

3

$\Delta V_{\text {Added }}=V_{U} \times\left([N a]_{U}+[K]_{U}\right)$

TABLE 4: Calculations of fluid deficits during management of extreme hyperglycemia

Water deficit at presentation is calculated as the difference between body water in the normal state and at presentation with hyperglycemia. Body water in the normal state is calculated by an appropriate anthropometric formula utilizing body weight at the normal state. Body water deficit is the difference between the normal body weight and the weight at presentation with hyperglycemia. Body water at presentation is the difference between the normal body water and the water deficit.

The water deficit determines the required volume of the initial replacement solution. Body monovalent cations are also calculated in the normal state and at presentation. The difference in monovalent cations between the baseline normal state and at presentation with hyperglycemia determines the cation composition of the initial replacement solution. Monitoring of ongoing losses of urine volume, sodium and potassium guide the selection of the additional replacement solutions. To illustrate these calculations, we will use data from an actual patient with preserved renal function who developed extreme hyperglycemia.

A 14-year-old boy with no prior history of diabetes mellitus was admitted with coma and seizures in the preceding 12 hours (Patient 2). He had a 10-day history of polyuria and profound thirst. He consumed up to 7.5 liters (2 gallons) per day of fluids, including solutions containing electrolytes. His blood pressure was unrecordable on admission. Six hours later, he was transferred to the Intensive Care Unit (ICU) of a second hospital after intravenous administration of insulin, pressors, and 5 liters of $0.154 \mathrm{~m}$ saline with potassium chloride, plus tracheal intubation and mechanical ventilation because of rising arterial $\mathrm{pCO}_{2}$. His height was $160 \mathrm{~cm}$. Body weight was $46.6 \mathrm{~kg}$ at his pediatrician's office 10 days prior to this admission, $36.8 \mathrm{~kg}$ on admission to the first hospital, and $40.2 \mathrm{~kg}$ upon admission to the second hospital.

At the second hospital, initial blood pressure was $64 / 36 \mathrm{~mm} \mathrm{Hg}$ and pulse rate 145 per minute. Urinalysis revealed glucose $>55.6 \mathrm{mmol} / \mathrm{l}(>1000 \mathrm{mg} / \mathrm{dl})$ and large amounts of acetone. Treatment continued with intravenous insulin and $0.3 \mathrm{~L}$ per hour of $0.154 \mathrm{~m}$ saline containing potassium acetate and potassium phosphate (total potassium concentration $35 \mathrm{mEq} / \mathrm{l}$ ). Throughout the course of the first 48 hours in the ICU of the second hospital, he exhibited marked diuresis, but urine volumes were not recorded. 


\section{Cureus}

Table 5 shows serum chemistries in the first 18 hours of treatment. The first set of values was obtained on admission in the first hospital, when he exhibited extreme hypertonicity and lifethreatening hypovolemia, addressed by large saline infusions. Parallel to volume repletion, correction of the extreme hypertonicity should be a primary aim of the treatment. To fulfill the recommendations of the guidelines $[1-2,4]$ as discussed earlier, $[G l u]_{S}$ should be normalized between 28.3 and 42.5 hours and corrected $[N a]_{S} \quad$ should decrease and be normalized between 32.2 and 48.3 hours.

\begin{tabular}{|l|l|l|l|l|l|l|l|}
\hline $\begin{array}{l}\text { Glucose } \\
\text { mmol/l } \\
\text { (mg/dl) }\end{array}$ & $\begin{array}{l}\text { Sodium } \\
\text { Measured } \\
\mathrm{mEq} / \mathrm{l}\end{array}$ & $\begin{array}{l}\text { Potassium } \\
\mathrm{mEq} / \mathrm{l}\end{array}$ & $\begin{array}{l}\text { Chloride } \\
\mathrm{mEq} / \mathrm{l}\end{array}$ & $\begin{array}{l}\text { Total CO2 } \\
\mathrm{mmol} / \mathrm{L}\end{array}$ & $\begin{array}{l}\text { Anion Gap } \\
\mathrm{mEq} / \mathrm{L}\end{array}$ & $\begin{array}{l}\text { Tonicity } \\
\mathrm{mOsm} / \mathrm{I}\end{array}$ & $\begin{array}{l}\text { Sodium } \\
\text { Corrected } \\
\mathrm{mEq} / \mathrm{l}\end{array}$ \\
\hline $123.7(2226)$ & 135 & 2.4 & 94 & 9 & 32 & 393.7 & 169.0 \\
\hline $99.7(1794)$ & 148 & 3.3 & 112 & 9 & 27 & 391.7 & 175.1 \\
\hline $98.9(1618)$ & 155 & 3.3 & 119 & 14 & 22 & 399.9 & 179.3 \\
\hline $70.7(1273)$ & 159 & 2.1 & 128 & 13 & 18 & 388.7 & 177.8 \\
\hline $68.8(1239)$ & 162 & 2.1 & 131 & 14 & 17 & 392.8 & 180.2 \\
\hline
\end{tabular}

TABLE 5: Sequential serum chemistry values in a hyperglycemic patient with profound diuresis treated with insulin infusion plus large fluid infusions. Patient 2.

Additional measurements on admission: In serum, urea $25.4 \mathrm{mmol} / \mathrm{l}$, creatinine $672.0 \mu \mathrm{mol} / \mathrm{l}$. In arterial blood, $\mathrm{pH} 7.209, \mathrm{pO} 2226$ $\mathrm{mm} \mathrm{Hg}$ (on $6 \mathrm{~L} / \mathrm{min}$ oxygen by face mask), pCO2 $16 \mathrm{~mm} \mathrm{Hg}$, and bicarbonate $6.2 \mathrm{mEq} / \mathrm{L}$. Additional serum measurements simultaneous with the last blood glucose value: Urea $19.3 \mathrm{mmol} / \mathrm{l}$, creatinine $336.0 \mu \mathrm{mol} / \mathrm{l}$.

Additional measurements on admission: In serum, urea $25.4 \mathrm{mmol} / \mathrm{l}$, creatinine $672.0 \mu \mathrm{mol} / \mathrm{l}$. In arterial blood, $\mathrm{pH} 7.209, p \mathrm{O}_{2} 226 \mathrm{~mm} \mathrm{Hg}$ (on $6 \mathrm{~L} / \mathrm{min}$ oxygen by face mask), $p \mathrm{CO}_{2} \quad 16 \mathrm{~mm}$ $\mathrm{Hg}$, and bicarbonate $6.2 \mathrm{mEq} / \mathrm{L}$. Additional serum measurements simultaneous with the last blood glucose value: Urea $19.3 \mathrm{mmol} / \mathrm{l}$, creatinine $336.0 \mu \mathrm{mol} / \mathrm{l}$.

During the period depicted in Table 5 , serum tonicity did not change in patient 2 despite a decrease in $[G l u]_{S}$ by almost $55.6 \mathrm{mmol} / \mathrm{l}$ at an average hourly rate of $3.2 \mathrm{mmol} / \mathrm{l}$, while corrected $[\mathrm{Na}]_{S}$ progressively increased in each sequential measurement. During the same period, the measured $[N a]_{S}$ increased by $2.74 \mathrm{mEq} / \mathrm{l}$ for each $5.6 \mathrm{mmol} / \mathrm{L}$ decrease in $[G l u]_{S}$ . This rate of increase in $[N a]_{S}$ is substantially higher than the one in Katz's formula. Figure 5 shows a progressive decline of the fraction of hypertonicity caused by hyperglycemia and a progressive rise of the fraction caused by external changes in water, sodium and potassium balance in the successive serum chemistry measurements shown in Table 5 . 


\section{Cureus}

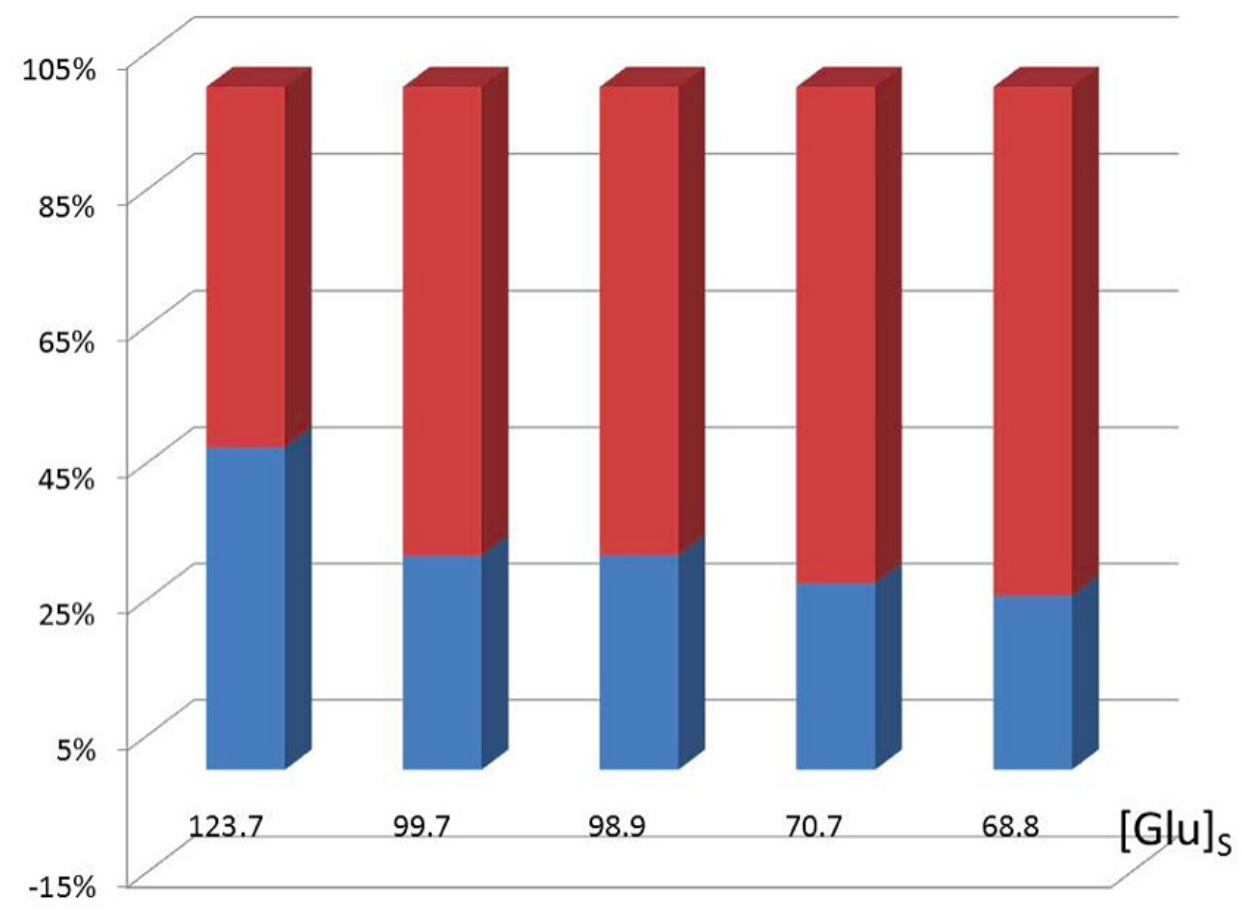

\section{FIGURE 5: Percents of hypertonicity attributable to}

hyperglycemia

Percents of hypertonicity attributable to hyperglycemia (blue) and to the net external losses of water and monovalent cations (red) corresponding to the serum glucose measurements presented in Table 5. Note that the absolute value of hypertonicity was almost the same in all five measurements. Hypertonicity secondary to hyperglycemia was computed as $2.4 \mathrm{mmol} / \mathrm{l}$ per $5.6 \mathrm{mmol} / \mathrm{l}$ rise in serum glucose concentration $(19,20)$.

At the time of the last set of values shown in Table 5, body weight was not measured, serum osmolality was $424 \mathrm{mOsm} / \mathrm{kg}$, while in urine osmolality was $526 \mathrm{mOsm} / \mathrm{kg}$, sodium $25 \mathrm{mEq} / \mathrm{l}$ and potassium $28 \mathrm{mEq} / \mathrm{l}$. He subsequently received intravenously large volumes of hypotonic saline with additional potassium salts and had a gradual improvement in his laboratory values and a slower improvement in his clinical status. He was extubated five days later and remained in the hospital for a total of 25 days. He was discharged on maintenance insulin. His serum creatinine returned to values below $80 \mu \mathrm{mol} / \mathrm{L}$. His mental status cleared, but he exhibited severe depression.

Using Table 4, the following estimates of water and cation deficits at presentation were calculated for patient 2: According to the Mellits-Cheek formula [47], shown as formula 6 in Table 2, body water in the normal state was 30.41 ; the sum of total body sodium, plus potassium, in the normal state was $4256.0(=140 \times 30.4) \mathrm{mEq}$; on admission to the first hospital, weight deficit was $9.8(=46.6-38.8) \mathrm{kg}$ and body water was $20.6(=30.4-9.8) 1$; total body sodium, plus potassium, on the same admission was 3481.4 (= $169 \times 20.6) \mathrm{mEq}$; sodium, plus potassium, deficit on the same admission was $774.6(=4256.0-3481.4) \mathrm{mEq}$.

The ideal replacement solution for losses that took place during development of hyperglycemia should have consisted of a volume of 9.81 and a combined concentration of sodium, plus potassium, of $79.0(=774.6 / 9.8) \mathrm{mEq} / \mathrm{l}$, or an isotonic infusion of $5.53(=774.6 / 140) \mathrm{l}$, plus an 
additional infusion of 4.27 (= $9.8-5.53)$ l of water. Instead, patient 2 continued to receive hypertonic infusions of salt with potassium salts, while he continued having hypotonic osmotic diuresis. Consequently, serum tonicity did not change, despite the large drop in $[G l u]_{S}$, while corrected $[\mathrm{Na}]_{S}$ rose continuously (Table 5) showing progressively larger water deficits.

Further calculations verified the progressive increase in water deficit during treatment suggested by Figure 5. During the stay in the first hospital, body weight increased from 36.8 to $40.2 \mathrm{~kg}$ indicating that 3.41 of the infused 51 were retained. On admission to the second hospital at a weight of $40.2 \mathrm{~kg}$, the calculated deficit of sodium, plus potassium, had decreased from 774.6 to only $56 \mathrm{mEq}$, while the water deficit had increased from 4.27 to 6.41 . Changes in body weight were not recorded subsequently. However, the rising values of corrected $[\mathrm{Na}]_{S}$ (Table 5) indicate further increases in the deficit of body water relatively to body sodium, plus potassium.

\section{Management of hyperglycemic abnormalities in body potassium and acid-base balance}

In addition to volume and tonicity, potassium balance and acid-base balance may become critical issues during treatment of hyperglycemia. Other issues, such as management of phosphate balance, are addressed in the guidelines [1-2, 4]. Hyperglycemia disrupts both the internal and the external potassium balance. Transfers of potassium outside the cells are caused by insulin deficits and hypertonicity [48]. Whether ketoacidosis or lactic acidosis also affect these transfers has been disputed because the transfer of monocarboxylic acids (e.g. ketoacids, lactic acid) through transporters in cell membranes has no direct effects on potassium transport [48]. However, changes in intracellular $\mathrm{pH}$ that accompany organic acidosis have indirect effects on potassium transport through other membrane transporters and exchangers [49]. In addition to $[G l u]_{S}$, multivariate analysis identified arterial $\mathrm{pH}$ and serum anion gap as predictors of plasma potassium concentration in a clinical study of diabetic ketoacidosis [50]. The disturbance of internal potassium balance secondary to hyperglycemia is clearly demonstrated by the frequency and severity of hyperkalemia in severe dialysis-associated hyperglycemia [51].

In patients with preserved renal function, loss of potassium through osmotic diuresis tempers the hyperkalemic effect of hyperglycemia. Serum potassium concentration at presentation may be high, normal, or low. Severe hypokalemia may have life-threatening consequences [52]. To address the eventuality of profound hypokalemia, immediate measurement of plasma potassium concentration by a blood gas analyzer has been proposed [53].

Low, or even normal, presenting serum potassium concentration $\left([K]_{S}\right)$ in hyperglycemia is associated with large potassium deficits.

During treatment of hyperglycemia, potassium is lost from the extracellular compartment to both the intracellular compartment and the urine, as long as there is osmotic diuresis. Furthermore, infusion of large amounts of fluids not containing potassium salts may lead to further decreases in $[K]_{S}$. Infusion of insulin and correction of hypertonicity cause potassium entry into the intracellular compartment. The effects of insulin on the intracellular transfers of potassium and glucose differ (54). A large decline in $[K]_{S}$ without any substantial change in $[G l u]_{S}$ was documented after administration of insulin to an anuric patient with severe hyperglycemia (55). Administration of potassium salts with saline infusions should precede insulin infusion if $[K]_{S}$ is not elevated at presentation with hyperglycemia $[1-2,4]$.

Despite administration of large amounts of potassium salts, intracellular transfers and urinary 
losses of potassium may result in persistent or worsening hypokalemia during treatment (Table 5). The consequences are potentially ominous [56]. Adjustments in the amounts of potassium infused guided by $[K]_{S}$ are frequently needed in severe hyperglycemia. Correction of large potassium deficits may require more than one week [57].

Multiple acid-base abnormalities may be present in hyperglycemia [58-59]. We will discuss only respiratory acidosis and metabolic acidosis because of their potential severity. Respiratory acidosis requiring intubation, as in the second patient of this report, may result from hypokalemia [52, 56-57], associated respiratory or neurological injury, or, in patients on chronic dialysis, hypervolemia [58]. Lactic acidosis is frequently encountered in severe hyperglycemic syndromes and may be confused with ketoacidosis [60]. Measurement of serum lactate level should accompany determination of serum ketone bodies at presentation with hyperglycemia and high-anion gap metabolic acidosis.

Appropriate response to treatment of DKA or lactic acidosis with insulin, plus fluids, is a rising serum $\mathrm{TCO}_{2}$ and decreasing serum anion gap, as in Table 5. Repeated measurements of ketone bodies and serum lactate are needed only if serum $\mathrm{TCO}_{2}$ decreases or anion gap increases during treatment. Sodium bicarbonate administration may be used in severe cases (2).

\section{Limitations}

There are several potential sources of error during treatment of severe hyperglycemia with profound water and electrolyte deficits. Water deficit estimates are based on body weight measurements, which are often inaccurate or unknown if recent weight determinations prior to the hyperglycemic episode are not available. The accuracy of the weighing procedure, often poor in hospital wards, should receive special emphasis during treatment of extreme hyperglycemia. Bedridden patients create added complexities in weight measurement.

The methods of estimating body water may further complicate the calculation of water deficits. Even at normal body weight, the margin of error of the anthropometric formulas estimating body water is in the order of a few liters. Used in subjects with substantial water deficits, these formulas systematically overestimate body water [61-64]. This was our reason for basing the estimates of body water on the normal euglycemic state in this report.

The uncertainties about the accuracy of the corrected $[N a]_{S}$ in hyperglycemic patients with preserved renal function have been discussed. Other influences that may cause deviations of the ratio $\frac{\Delta[N a]_{S}}{\Delta[G l u]_{S}} \quad$ from Katz's prediction include extracellular volume abnormalities [65-66], internal transfers of potassium [67], and the degree of hyperglycemia [68]. Among these, extracellular volume abnormalities are, by far, the most important [69]. Also, the rates of transfer of the infused potassium into the intracellular compartment can be inferred from external balances, but cannot be directly measured in the clinical practice and, more importantly, cannot be predicted. The final source of potential errors is loss of fluid or cations from the gastrointestinal tract, the respiratory system or the skin during treatment.

For all these reasons, frequent monitoring of the clinical status, especially volume and neurological status, and urine output of the patients, as well as of the relevant laboratory values, is critical during treatment. In addition to indicating whether clinical status and laboratory tests are improving, monitoring allows comparisons with the predictions of the quantitative system shown in Table 4. Deviations of the measurements from the predicted values should cause a search for conditions which may cause such deviations, for example, large extrarenal losses. 


\section{Conclusions}

Repletion of deficits in volume and correction of the hypertonicity encountered in severe hyperglycemia should be made by using quantitative estimates of these deficits. Comparison of these estimates to the corresponding changes in volume and tonicity during treatment allows detection of deviations from desired end-points. Detection of such deviations warrants reexamining the calculation of the quantitative estimates and for a search for other conditions, such as ongoing extrarenal losses, affecting fluid solute and solute balances. Deficits of potassium, for which currently there are no quantitative estimates, and correction of acid-base abnormalities are also critical parts of the management of severe hyperglycemia. Regardless of whether quantitative estimates predicting deficits are available or not, monitoring of the clinical status and of appropriate laboratory values intervals are the critical parts of the management of extreme hyperglycemia.

\section{Additional Information}

\section{Disclosures}

Conflicts of interest: In compliance with the ICMJE uniform disclosure form, all authors declare the following: Payment/services info: Dr. Shapiro acknowledges support from the National Institutes of Health (HL109015 to JI Shapiro and Z Xie as multiple PIs and HL 105649 to J Tian as PI, JI Shapiro CoI). Financial relationships: All authors have declared that they have no financial relationships at present or within the previous three years with any organizations that might have an interest in the submitted work. Other relationships: All authors have declared that there are no other relationships or activities that could appear to have influenced the submitted work.

\section{Acknowledgements}

Dr. Tzamaloukas was responsible for conceiving and designing this work, analyzing and interpreting the data, composing the first draft and revising critically the draft for important intellectual content. Dr. Sun contributed to the conception of this work, was involved in the analysis of the data, and made critical revisions of the draft for important intellectual content. Mr. Konstantinov was involved in the analysis and interpretation of the data. Drs Ing, Dorin, Malhotra and Murata made critical contributions in the revisions of the draft for important intellectual content. Dr. Shapiro contributed to the conception of this work, the composition of the first draft, and made critical contributions in the revisions of the draft for important intellectual content.

\section{References}

1. Kitabchi AE, Umpierrez GE, Miles JM, Fisher JN: Hyperglycemic crises in adult patients with diabetes. Diabetes Care. 2009, 32:1335-1343.

2. Kitabchi AE, Umpierrez GE, Murphy MB, Kreisberg RA: Hyperglycemic crises in adult patients with diabetes. Diabetes Care. 2006, 29:2739-2748.

3. Dunger DB, Sperling MA, Acerini CL, Bohn DJ, Daneman D, Danne TP, Glaser NS, Hanas R, Hintz RL, Levitsky LL, Savage MO, Tasker RC, Wolfsdorf JI: European Society for Paediatric Endocrinology/Lawson Wilkins Pediatric Endocrine Society Consensus Statement on Diabetic Ketoacidosis in Children and Adolescents. Pediatrics. 2004, 113:E133-140.

4. Kitabchi AE, Umpierrez G, Murphy MB, Barrett EJ, Kreisberg RA, Malone JE, Wall BM: Hyperglycemic crises in diabetes . Diabetes Care. 2004, 27(Suppl 1):S94-S102.

5. Ilag LL, Kronick S, Ernst RD, Grondin L, Alaniz C, Liu L, Herman WH: Impact of a critical pathway on inpatient management of diabetic ketoacidosis. Diabetes Res Clin Pract. 2003, 62:23-32.

6. Volkova NB, Fletcher CC, Tevendale RW, Munyaradzi SM, Elliott S, Peterson MW: Impact of a multidisciplinary approach to guideline implementation in diabetic ketoacidosis. Am J Med 
Quality. 2008, 23:47-55.

7. Bartoli E, Guidetti F, Bergamasco L: Estimating excess glucose, sodium and water deficits in non-ketotic hyperglycaemia. Nephrol Dial Transplant. 2007, 22:3478-3486.

8. Bartoli E, Bergamasco L, Castello L, Sainaghi PP: Methods for quantitative assessment of electrolyte disturbance in hyperglycaemia. Nutr Metab Cardiovasc Dis. 2009, 19:67-74.

9. Feig PU, McCurdy DK: The hypertonic state. NEJM. 1977, 297:1444-1454.

10. Pollock AS, Arieff AI: Abnormalities of cell volume regulation and their functional consequences. Am J Physiol . 1980, 239:F195-F205.

11. Adrogue HJ, Madias NE: Hypernatremia. NEJM. 2000, 342:1493-1499.

12. Adrogue HJ, Madias NE: Hyponatremia. NEJM. 2000, 342:1581-1589.

13. Lien Y-HH, Shapiro JI: Hyponatremia: Clinical diagnosis and management. Am J Med. 2007, 120:653-658.

14. Schrier RW, Bansal S: Diagnosis and management of hyponatremia in acute illness . Curr Opin Crit Care. 2008, 12:627-634.

15. Tzamaloukas AH, Malhotra D, Rosen BH, Raj DSC, Murata GH, Shapiro JI: Principles of management of severe hyponatremia. J Am Heart Assoc. 2013, 2:e005199.

10.1161/JAHA.112.005199

16. Seldin DW, Tarail R: The metabolism of glucose and electrolytes in diabetic acidosis . J Clin Invest. 1950, 29:552-565.

17. McCurdy DK: Hyperosmolar hyperglycemic nonketotic diabetic coma. Med Clin North Am. 1970, 54:683-699.

18. Tomkins AM, Dormandy TL: Osmolal pattern during recovery from diabetic coma . Lancet. 1971, 2:952-955.

19. Tzamaloukas AH, Levinstone AR, Gardner KD., Jr: Hyperglycemia in advanced renal failure: Sodium and water metabolism. Nephron. 1982, 31:40-44.

20. Katz MA: Hyperglycemia-induced hyponatremia: Calculation of the expected serum sodium depression. NEJM. 1973, 289:843-844.

21. Al-Kudsi RR, Daugirdas JT, Ing TS, Kheirbek AO, Popli S, Hano JE, Gandhi VL: Extreme hyperglycemia in dialysis patients. Clin Nephrol. 1982, 17:228-231.

22. Maccario M: Neurological dysfunction associated with nonketotic hyperglycemia . Arch Neurol. 1968, 19:525-534.

23. Kaldany A, Curt GA, Estes NM, Weinrauch LA, Christlieb AR, D’Elia JA: Reversible acute pulmonary edema due to uncontrolled hyperglycemia in diabetic individuals with renal failure. Diabetes Care. 1982, 5:506-511.

24. Tzamaloukas AH, Rohrscheib M, Ing TS, Siamopoulos KC, Elisaf MF, Spalding CT: Serum tonicity, extracellular volume and clinical manifestations in symptomatic dialysis-associated hyperglycemia treated only with insulin. Int J Artif Organs. 2004, 27:751-758.

25. Tzamaloukas AH, Ing TS, Siamopoulos KC, Rohrscheib M, Elisaf MS, Raj DSC, Murata GH: Body fluid abnormalities in severe hyperglycemia in patients on chronic dialysis: review of published reports. J Diabetes Complications. 2008, 22:29-37.

26. Penne EL, Thijssen S, Raimann JG, Levin NW, Kotanko P: Correction of serum sodium for serum glucose concentration in hemodialysis patients with poor glucose control. Diabetes Care. 2010, 33:E91.

27. Tzamaloukas AH, Murata GH, Siamopoulos KC, Raj DSC, Elisaf MS, Rohrscheib M, Ing TS: Pathophysiology and management of severe hyperglycemia in patients on chronic dialysis . Semin Dial. 2008, 21:431-439.

28. Tzamaloukas AH, Avasthi PS: Effect of serum sodium concentration and tonicity in outpatients on chronic dialysis. Am J Kidney Dis. 1986, 7:477-482.

29. Ifudu O, Dulin AL, Friedman EA: Interdialytic weight gain correlates with glycosylated hemoglobin in diabetic hemodialysis patients. Am J Kidney Dis. 1994, 23:686-691.

30. Ramdeen G, Tzamaloukas AH, Malhotra D, Leger A, Murata GH: Estimates of interdialytic sodium and water intake based on the balance principle. Differences between nondiabetic and diabetic subjects on hemodialysis. Am Soc Artif Intern Organs J. 1998, 44:812-817.

31. Tzamaloukas AH: Prediction of the change in extracellular sodium concentration in hyperglycemia complicated by severe losses of water and solute. Clin Chem. 1982, 28:17221724.

32. Nanzi A: Hyperglycemia-induced hyponatremia: A clinical study to validate a correction factor. Clin Chem. 1981, 27:1771-1773. 
33. McNair P, Madsbad S, Christiansen C, Christensen MS, Transbol I: Hyponatremia and hyperkalemia in relation to hyperglycemia in insulin-treated diabetic out-patients. Clin Chim Acta. 1982, 120:243-250.

34. Strand CL, Garcia H, Costales I: Hyponatremia in spontaneous hyperglycemia: Correlation studies in 100 patients. Clin Chem. 1987, 33:1941-1942.

35. Hillier TA, Abbott RD, Barrett EJ: Hyponatremia: Evaluating the correction factor for hyperglycemia. Am J Med. 1999, 106:399-403.

36. Kurtz I, Nguyen MK: Evolving concepts in the quantitative analysis of the determinants of the plasma water sodium concentration and the pathophysiology of dysnatremias. Kidney Int. 2005, 68:1982-1993.

37. Arieff AI, Carroll HJ: Nonketotic hyperosmolar coma with hyperglycemia . Medicine (Baltimore). 1972, 51:73-94.

38. Gennari FJ, Kassirer JP: Osmotic diuresis. NEJM. 1974, 291:714-720.

39. Seldin DW, Tarail R: Effect of hypertonic solutions on metabolism and excretion of electrolytes. Am J Physiol. 1949, 159:160-174.

40. Brodsky WA, Rapoport S, West CD: The mechanism of glycosuric diuresis in diabetic man . J Clin Invest. 1950, 159:1021-1032.

41. de Wardener, HE: The Kidney: An Outline of Normal and Abnormal Structure and Function, 2nd edition. J.\& A. Churchill, Ltd, London UK; 1961, pp 47-48.

42. Edelman IS, Leibman O, O'Meara MP, Birkenfeld, LW: Interrelations between serum sodium concentration, serum osmolality and total exchangeable sodium, total exchangeable potassium and total body water. J Clin Invest. 1958, 37:1236-1246.

43. Goldberg M: Hyponatremia. Med Clin North Am. 1981, 65:251-269.

44. Leehey DJ, Daugirdas JT, Manahan FJ, Kellner KJ, Ing TS: Prolonged hypernatremia associated with azotemia and hyponatriuria. Am J Med. 1989, 86:494- 496.

45. Linder G, Schwarz C, Funk GC: Osmotic diuresis due to urea as the cause of hypernatremia in critically ill patients. Nephrol Dial Transplant. 2012, 27:962-967.

46. Popli S, Tzamaloukas AH, Ing TS: Osmotic diuresis-induced hypernatremia: better explained by solute-free water clearance or electrolyte-free water clearance?. Int Urol Nephrol. e-pub January, 2013, 10.1007/s11255-012-0353-3

47. Mellits ED, Cheek DB: The assessment of body water and fatness from infancy to adulthood . Mon Soc Res Child Dev . 1970, 35:12-26.

48. Tzamaloukas AH, Ing TS, Elisaf MS, Raj DSC, Siamopoulos KC, Rohrscheib M, Murata GH: Abnormalities in serum potassium concentration in dialysis-associated hyperglycemia and their correction with insulin: a unique clinical/physiologic exercise in internal potassium balance. Int Urol Nephrol. 2010, 42:1015-1022.

49. Aronson PS, Giebisch G: Effects of $\mathrm{pH}$ on potassium: new explanations for old observations . J Am Soc Nephrol. 2011, 22:1981-1989.

50. Adrogue HJ, Lederer ED, Suki WK, Eknoyan G: Determinants of plasma potassium levels in diabetic ketoacidosis. Medicine (Baltimore). 1986, 65:163-172.

51. Tzamaloukas AH, Ing TS, Elisaf MS, Raj DSC, Siamopoulos KC, Rohrscheib M, Murata GH: Abnormalities in serum potassium concentration in dialysis-associated hyperglycemia and their correction with insulin: Review of published reports. Int Urol Nephrol. 2011, 43:451459.

52. Dorin RI, Crapo LM: Hypokalemic respiratory arrest in diabetic ketoacidosis . JAMA. 1987, 257:1517-1518.

53. Leventhal RI, Goldman JM: Immediate plasma potassium levels in treating diabetic ketoacidosis. Arch Intern Med. 1987, 47:1501-1502.

54. Nguyen TQ, Maalouf NM, Sakhaee K, Moe OW: Comparison of insulin action on glucose versus potassium uptake in humans. Clin J Am Soc Nephrol. 2011, 6:1533-1539.

55. Gupta A, Rohrscheib M, Tzamaloukas AH: Extreme hyperglycemia with ketoacidosis and hyperkalemia in a patient on chronic hemodialysis. Hemodialysis Int. 2008, 12:S43-S47.

56. Krentz AJ, Ryder RE: Hypokalemia-induced respiratory failure complicating treatment of diabetic ketoacidosis. J Diabetes Complications. 1994, 8:55-56.

57. Murthy K, Harrington JT, Siegel RD: Profound hypokalemia in diabetic ketoacidosis: a therapeutic challenge. Endocr Pract. 2005, 11:331-334.

58. Tzamaloukas AH, Avasthi PS: Acid-base disorders in hyperglycemia of insulin- dependent diabetic patients on chronic dialysis. J Diabetes Complications. 1988, 2:75-78. 
59. Elisaf MS, Tsatsoulis AA, Katopodis KP, Siamopoulos KC: Acid-base and electrolyte disturbances in patients with diabetic ketoacidosis. Diabetes Res Clin Pract . 1996, 34:23-27.

60. Tillman CR: Hypokalemic hypoventilation complicating severe diabetic ketoacidosis. South Med J . 1980, 73:231-233.

61. English P, Williams G: Hyperglycemic crises and lactic acidosis in diabetes mellitus . Postgrad Med J. 2004, 80:253-261.

62. Tzamaloukas AH: Effect of edema on urea kinetic studies in peritoneal dialysis . Perit Dial Int. 1994, 14:398-401.

63. Tzamaloukas AH, Murata GH, Dimitriadis A, Voudiklari S, Antoniou S, Malhotra D, Kakavas J, Dombros NV, Nikolopoulou N, Balaskas EV: Fractional urea clearance in continuous peritoneal dialysis: Effects of volume disturbances. Nephron. 1996, 74:567-571.

64. Tzamaloukas AH, Murata GH, VanderJagt DJ, Glew RH: Estimates of body water, fat- free mass and body fat in patients on peritoneal dialysis by anthropometric formulas. Kidney Int. 2003, 63:1605-1617.

65. Moran SM, Jamison RL: The variable hyponatremic response to hyperglycemia . West J Med. 1985, 142:49-53.

66. Tzamaloukas AH, Kyner WT, Galley WR, Jr: Determinants of osmotic phenomena created by an isolated change in extracellular solute in anuria. Miner Electrolyte Metab. 1987, 13:117125.

67. Roscoe JM, Halperin ML, Rolleston FS, Golstein MN: Hyperglycemia-induced hyponatremia: Metabolic considerations in calculation of serum sodium concentration. Can Med Assoc J. 1975, 112:452-453.

68. Robin AP, Ing TS, Lancaster GA, Soung LS, Sparagana M, Geis WP, Hano JE: Hyperglycemiainduced hyponatremia: A fresh look. Clin Chem. 1979, 25:496-497.

69. Tzamaloukas AH, Ing TS, Siamopoulos KC, Rohrscheib M, Elisaf MS, Raj DSC, Murata GH: Body fluid abnormalities in severe hyperglycemia in patients on chronic dialysis: theoretical analysis. J Diabetes Complications. 2007, 21:374-380. 